\section{Growth Habit Determination of Genotypes of African Bermudagrass}

\author{
Kevin E. Kenworthy ${ }^{1}$ \\ Department of Agbusiness, Agronomy, Horticulture and Range Management, \\ Tarleton State University, Box T-0050, Stephenville, TX 76402; and the \\ University of Florida, Agronomy Department, 304 Newell Hall, Gainesville, \\ FL 32611-0500 \\ Dennis L. Martin \\ Department of Horticulture \& Landscape Architecture, Oklahoma State \\ University, Stillwater, OK 74078
}

\section{Charles M. Taliaferro \\ Department of Plant \& Soil Sciences, Oklahoma State University, Stillwater, OK 74078}

Additional index words. Cynodon transvaalensis, African bermudagrass, bermudagrass, turfgrass, germplasm

\begin{abstract}
Six African bermudagrass (Cynodon transvaalensis Burtt-Davy) genotypes, one common bermudagrass $[C$. dactylon (L.) Pers. var. dactylon] genotype, and 'Tifway' $(C$. dactylon $\times$ transvaalensis) hybrid bermudagrass were evaluated for shoot type, leaf angle, and shoot angle. Evaluations were conducted to determine if these measurements could be used to differentiate among upright, intermediate, and prostrate growth habits. Significant differences were found for all three techniques, but attempts to group plants together as having prostrate, intermediate, or upright growth habits was not possible. 'Tifway' was intermediate between the African bermudagrass genotypes and the common genotype for shoot type observations, but was more similar to upright-growing African bermudagrass for leaf angle and the more prostrate-growing common bermudagrass for shoot angle. Quantification of shoot type and leaf angle did not appear as useful as shoot angle measurements for screening germplasm to identify upright or prostrate growth habits in bermudagrass.
\end{abstract}

Within the Cynodon genus, there are nine species (Harlan et al., 1970a). Two Cynodon taxa, C. dactylon (L.) Pers. var. dactylon and C. transvaalensis Burtt-Davy, are important to the turfgrass industry. Tetraploid $(2 \mathrm{n}=$ $4 \mathrm{x}=36)$ C. dactylon var. dactylon is widely distributed between north and south latitudes of $\approx 45^{\circ}$ and highly polymorphic (Harlan and de Wet, 1969; Harlan et al., 1970b). Genetic variation for growth morphology within common bermudagrass is well documented with plant types ranging from relatively small, fine textured, turf types to robust forage types (Harlan and de Wet, 1969; Harlan et al., 1970b). Because of its widespread distribution and prevalence, it is frequently referred to as "common" bermudagrass. Diploid $(2 \mathrm{n}=$ $2 \mathrm{x}=18)$ C. transvaalensis, often referred to as African bermudagrass, is indigenous only to the Transvaal region of South Africa (de Wet and Harlan, 1971) and is characterized as small, short in stature, fine-textured, yellow-green in color, and having hairy, erect leaves (Hanna, 1986; Harlan et al., 1966, 1970a, 1970b; Juska and Hanson, 1964). The

Received for publication 5 Apr. 2007. Accepted for publication 24 June 2007.

${ }^{1}$ To whom reprint requests should be addressed; e-mail kenworth@ufl.edu. vars that have become industry standards and result from hybridization between plants of common and African bermudagrass.

Reasons for the success of the interspecific hybrid cultivars in comparison with intraspecific cultivars have not been elucidated but undoubtedly are the result of the combining of desirable traits from the two respective species. Elite $F_{1}$ interspecific hybrid plants combine the generally superior traits of common bermudagrass (darker green color, greater turf performance stability, and superior performance under moderate levels of fertility/cultural management) with the generally superior traits of African bermudagrass (fine texture and greater sod density).

Various morphological growth traits of Kentucky bluegrass have been characterized through measurement of plant structures. Nittler and Kenny (1976) evaluated Kentucky bluegrass cultivars for differences in crown type. They classified crowns as compact, semicompact, semispreading, or spreading. Compact crowns grew upward with no lateral growth, whereas spreading crowns grew laterally $1 \mathrm{~cm}$ or more before turning upward. Semispreading crowns contain tillers that grew laterally 0.5 to less than $1 \mathrm{~cm}$ before turning upward, and semicompact crowns contain tillers that spread less than $0.5 \mathrm{~cm}$ before turning upward.

Eggens (1981) measured the tiller orientation of 11 Kentucky bluegrass cultivars. Tillers were classified as prostrate when the angle between the tiller and the soil surface was less than $30^{\circ}$, intermediate when the angle was between $30^{\circ}$ and $59^{\circ}$, and upright when the tiller was at an angle of greater than $60^{\circ}$ from the soil surface.

Burt and Christians (1990) measured the leaf angle of Kentucky bluegrass cultivars characterized as differing in maintenance requirement (low versus high). They measured the leaf angle from the horizontal soil surface and found that the low-maintenance cultivars had greater leaf angles than did the high-maintenance cultivars.

We used similar measurements as those used for Kentucky bluegrass in an attempt to characterize plant architecture and growth habit of African, common, and hybrid turf bermudagrass genotypes. Specific objectives were 1) to determine if observations of shoot type (crown type) and measurements of shoot and leaf angles could be used to detect differences within and among bermudagrass species; 2) to determine, like in Kentucky bluegrass, if bermudagrass can be designated as having branching or nonbranching shoots and if leaf and shoot angles can be labeled as prostrate, upright, or intermediate; and 3) to determine which of these techniques might be more useful in screening germplasm to identify plants with a more upright or prostrate growth habit.

\section{Materials and Methods}

Six African bermudagrass (designated $\mathrm{Ct}$ series) genotypes were evaluated. These genotypes were selected from a previously 
developed genetic population of African plants that had been rated visually for their growth habit. Table 1 contains the selected African genotypes with their corresponding visual growth habit rating. All African bermudagrass genotypes were easily identifiable as C. transvaalensis except for $\mathrm{Ct}$ 5-7-5, which could be considered a dwarf when compared with the other plants. For comparison, a common bermudagrass genotype (UFC-22, selected near Stephenville, TX, for its density and prostrate growth habit) and the hybrid cultivar 'Tifway' (C. dactylon $\times$ transvaalensis) were included (Table 1).

In early May 2003, all genotypes were propagated in $10.2-\mathrm{cm}$ diameter pots in the greenhouse. When pots were grown-in, they were planted 25 June 2003 in a randomized complete block design with three replications per treatment at the Tarleton State University Turfgrass Facility on a Lindy Loam soil (fine, mixed, active, thermic udic haplustalf) with four pots evenly spaced near the plot corners and one pot in the plot center. A plot consisted of a genotype, and individual plots measured $2.3 \mathrm{~m}^{2}$. The experiment was fertilized at a rate of $48.4 \mathrm{~kg} \cdot \mathrm{ha}^{-1}$ of nitrogen per growing month, watered to encourage growth, and mowed weekly at a height of $5.1 \mathrm{~cm}$. The higher mowing height allowed for easier access to turfgrass shoots for measurement purposes. Soil analysis indicated a $\mathrm{pH}$ of 7.5.

Evaluated traits included shoot type, leaf angle orientation, and shoot angle orientation. Five samples were collected for each trait from each plot. Efforts were then made to use the data to group the African bermudagrass plants and assign labels describing growth habits as prostrate, intermediate, or upright.

Bermudagrass produces and spreads through both rhizomes and stolons; therefore, designation as branching or nonbranching aboveground shoot type was used versus crown types according to Nittler and Kenny (1976). Nonbranching indicates that a single shoot was arising through the soil surface and branching is defined as multiple shoots arising from a single node (as occurs on stolons). Nonbranching shoots were assigned a value of one and branching shoots a value of two. This was achieved through visual inspection of randomly selected aboveground shoots. Subsequent measurements were performed on the same shoot.

Leaf orientation was measured as the angle from the horizontal soil surface using a protractor. Therefore, greater angles were associated with more upright leaves. Leaf measurements were taken from mature leaves that had not recently been mown.

Shoot orientation was also measured as the angle between the stem and the soil surface using a protractor. If a node contained multiple shoots, the most mature shoot was used for measurements.

Because of possible environmental influences on plant growth and development, data for each parameter were collected on three dates. Measurements were collected 20 Aug., 2003, 28 Oct., 2003, and 21 May 2004.
African bermudagrass grows best during spring, late summer, and fall. Turf quality will generally decline through summer; therefore, measurements were not made in June and July to avoid collection of data during periods of inadequate growth.

For analysis, the five subsamples were averaged per plot. Data were analyzed using the PROC GLM procedure of SAS (SAS Institute, 2000) and means separated using Fisher's least significant difference (LSD) at the $5 \%$ significance level. The data were analyzed as a split plot with genotypes designated as main plots and measurement dates as subplots.

\section{Results and Discussion}

A significant genotype $\times$ date $(\mathrm{G} \times \mathrm{D}$; $P \leq 0.01)$ interaction occurred for shoot angles, but not for shoot type or leaf angles (Table 2). Therefore, analysis for shoot types and leaf angles was pooled across dates; however, each date was analyzed separately for shoot angles. The pooled analysis of variance indicated highly significant differences $(P \leq 0.01)$ among genotypes for shoot type and leaf angle (Table 2). Differences between dates of measurement were also highly significant $(P<0.01)$ for shoot angles, but not for shoot type or leaf angles (Table 2).

Shoot type. In bermudagrass, all aboveground shoots originate from either stolons or rhizomes. If an aboveground shoot was a single plant with no branching, it was assumed to have arisen from an underlying rhizome. If an aboveground shoot was branching, then it was associated with a stolon. Differences in the extent of branching were found; however, the variation between genotypes prevented clear classification of shoot types, as done by Nittler and Kenny (1976) on Kentucky bluegrass, with the exception of the extremes.

The mean overall shoot type rating was 1.6 and ranged from 1.4 to 1.8 (Table 3 ). Two African bermudagrass genotypes (Ct 2-13-4 and $\mathrm{Ct}$ 1-14-5) had shoot type ratings significantly lower than all other genotypes except Ct 2-19-1, indicating less branching. Genotypes Ct 2-19-1, Ct 1-1-1, Ct 4-21-3, and Ct 5-7-5 did not differ from 'Tifway' (1.6) and Ct 5-7-5 and Ct 4-21-3 (both visually prostrate) were not significantly different from the common genotype (1.8).

The data support the association of branching shoots with a more prostrate growth habit; however, when plots matured, it became difficult to follow a stolon or stem back to its node of origin. Although characterization of shoot type may be a useful evaluation tool during establishment, its accuracy will decrease over time. For these reasons, this type of evaluation may not be useful on germplasm plots of established bermudagrass. However, because the $\mathrm{G} \times \mathrm{D}$ interaction was not significant, the pooled analysis and results described previously were kept intact.
Table 1. Bermudagrass genotypes that were used for growth habit determination.

\begin{tabular}{ll}
\hline Genotype & $\begin{array}{c}\text { Growth habit } \\
\text { rating }\end{array}$ \\
\hline Ct $1-1-1$ & Upright \\
Ct $1-14-5$ & Upright \\
Ct $2-13-4$ & Upright \\
Ct $2-19-1$ & Intermediate \\
Ct $4-21-3$ & Prostrate \\
Ct $5-7-5$ & Prostrate \\
UFC-22 (common) & Prostrate \\
Tifway & Intermediate \\
\hline
\end{tabular}

Table 2. Analysis of variance for shoot type, leaf angle, and shoot angle for six African bermudagrass genotypes, one common bermudagrass genotype, and Tifway hybrid bermudagrass.

\begin{tabular}{lrlcr}
\hline & & \multicolumn{3}{c}{ F values } \\
\cline { 3 - 5 } Source & df & $\begin{array}{c}\text { Shoot } \\
\text { type }\end{array}$ & $\begin{array}{c}\text { Leaf } \\
\text { angle }\end{array}$ & $\begin{array}{c}\text { Shoot } \\
\text { angle }\end{array}$ \\
\hline Blocks & 2 & & & \\
Genotype (G) & 7 & $5.42^{* *}$ & $7.58^{* *}$ & $21.75^{* *}$ \\
Error a & 14 & & & \\
Date (D) & 2 & $3.28^{*}$ & $3.86^{*}$ & $16.21^{* *}$ \\
G $\times \mathrm{D}$ & 14 & $1.11 \mathrm{NS}$ & $1.43 \mathrm{NS}$ & $2.24^{* *}$ \\
Error b & 32 & & & \\
Ns,****NNonsignificant & or significant at $P \leq 0.05$ or \\
0.01, respectively.
\end{tabular}

Table 3. Mean separation of shoot-types and leaf angles for six African bermudagrass genotypes, common bermudagrass, and Tifway hybrid bermudagrass.

\begin{tabular}{lcc}
\hline Genotype & Shoot type $^{\mathrm{z}}$ & Leaf angle $^{\mathrm{y}}$ \\
\hline Ct 2-13-4 & 1.4 & 65.0 \\
Ct 1-14-5 & 1.4 & 54.0 \\
Ct 2-19-1 & 1.5 & 53.0 \\
Ct 1-1-1 & 1.6 & 58.0 \\
Tifway & 1.6 & 56.0 \\
Ct 4-21-3 & 1.7 & 50.0 \\
Ct 5-7-5 & 1.8 & 40.0 \\
Common & 1.8 & 42.0 \\
LSD $^{\mathrm{x}}(0.05)$ & 0.2 & 8.0 \\
Mean & 1.6 & $52.0^{\circ}$ \\
\hline
\end{tabular}

${ }^{2}$ Nonbranching shoots were assigned a value of one and branching shoots were assigned a value of 2 . ${ }^{\mathrm{y}}$ Measured as the angle from the horizontal soil surface using a protractor.

${ }^{x}$ Means within a column that differ by more than the least significant difference (LSD) value differ at the 0.05 level of probability.

Leaf angle. Attempts were made to group specific ranges of leaf angles as prostrate, intermediate, or upright. However, the analysis did not provide groups of genotypes and prevented the assignment of these labels. Extreme leaf angles (high and low) were easily identifiable, but it should be noted that a given leaf angle was largely influenced by the shoot angle. For instance, a leaf growing perpendicular to its stem would have a smaller angle on an upright shoot versus a prostrate shoot. This secondary influence on the resulting leaf angle may explain why the majority of genotypes were statistically grouped together and should serve as caution for the use of this method to screen germplasm. 
The overall mean leaf angle was $52^{\circ}$ and ranged from $40^{\circ}$ to $65^{\circ}$ (Table 3). Ct 2-13-4 had the most upright mean leaf angle. It did not differ from $\mathrm{Ct} 1-1-1\left(58^{\circ}\right)$, which was similar to 'Tifway' $\left(56^{\circ}\right)$. In fact, 'Tifway' had one of the more upright leaf angles; however, it did not differ significantly from most genotypes studied. Only three genotypes were significantly different from 'Tifway'; Ct 5-7-5 and common bermudagrass had lower leaf angles, whereas the leaf angle of $\mathrm{Ct}$ 2-13-4 was higher. With respect to common bermudagrass $\left(42^{\circ}\right)$, all genotypes except two, Ct 4-21-3 and Ct 5-7-5, had significantly higher leaf angles.

Shoot angle. As a result of a significant $\mathrm{G} \times \mathrm{D}$ interaction $(P \leq 0.01)$, each date of measurement was analyzed independently. Each date indicated that differences do exist in bermudagrass for mean shoot angles (Table 4). Mean separation of each date was generally more straightforward for shoot angle measurements than for shoot types or leaf angles. Like with shoot types and leaf angles, grouping entries for assignment of prostrate, upright, or intermediate shoot angles was not possible.

On 20 Aug. 2003, the average shoot angle was $61^{\circ}$ and ranged from $35^{\circ}$ to $80^{\circ}$ (Table 4). Mean separation resulted in four African bermudagrass genotypes (Ct 1-14-5, Ct 1-1-1, Ct 2-19-1, and Ct 2-13-4) in the statistical grouping with the highest shoot angles $\left(71^{\circ}\right.$ to $80^{\circ}$ ). All genotypes in this group were significantly different from other African genotypes, 'Tifway', and common bermudagrass. 'Tifway' $\left(49^{\circ}\right)$ was not significantly different from Ct $4-21-3\left(57^{\circ}\right)$ or Ct 5-7-5 $\left(48^{\circ}\right)$. Common bermudagrass had the lowest shoot angle $\left(35^{\circ}\right)$, but was similar to $\mathrm{Ct}$ 5-7-5.

On 28 Oct. 2003, the average shoot angle was $53^{\circ}$ and ranged from $23^{\circ}$ to $78^{\circ}$. Three African genotypes, Ct 2-13-4, Ct 2-19-1, and Ct 1-14-5, had the highest shoot angles and were not statistically different $\left(73^{\circ}\right.$ to $\left.78^{\circ}\right)$. These three genotypes had statistically higher shoot angles than all other entries. 'Tifway' $\left(43^{\circ}\right)$ was similar to $\mathrm{Ct} 1-1-1\left(50^{\circ}\right), \mathrm{Ct} 4-21-3$

Table 4. Mean separation of shoot angles on three dates for six African bermudagrass genotypes, common bermudagrass, and Tifway hybrid bermudagrass.

\begin{tabular}{lccc}
\hline & \multicolumn{3}{c}{ Shoot angle $^{\mathrm{z}}$} \\
\cline { 2 - 4 } Genotype & 20 Aug. & 28 Oct. & 21 May \\
\hline Ct 1-14-5 & 80.0 & 73.0 & 76.0 \\
Ct 1-1-1 & 76.0 & 50.0 & 69.0 \\
Ct 2-19-1 & 73.0 & 77.0 & 75.0 \\
Ct 2-13-4 & 71.0 & 78.0 & 82.0 \\
Ct 4-21-3 & 57.0 & 49.0 & 69.0 \\
Tifway & 49.0 & 43.0 & 55.0 \\
Ct 5-7-5 & 45.0 & 32.0 & 57.0 \\
Common & 35.0 & 23.0 & 43.0 \\
LSD $^{\mathrm{y}}(0.05)$ & 11.0 & 14.0 & 11.0 \\
Mean & $61.0^{\circ}$ & $53.0^{\circ}$ & $66.0^{\circ}$ \\
\hline
\end{tabular}

${ }^{\mathrm{z}}$ Measured as the angle from the horizontal soil surface using a protractor.

${ }^{y}$ Means within a column that differ by more than the least significant difference (LSD) value differ at the 0.05 level of probability. $\left(49^{\circ}\right)$, and Ct 5-7-5 (32 $)$. Common bermudagrass had the lowest shoot angle $\left(23^{\circ}\right)$ and was significantly different from all other entries except $\mathrm{Ct}$ 5-7-5.

On 21 May 2004, the average shoot angle was $66^{\circ}$ and ranged from $43^{\circ}$ to $82^{\circ}$ (Table 4 ). Ct 2-13-4 had the highest shoot angle. Ct 1 14-5 and Ct 2-19-1 with shoot angles of $76^{\circ}$ and $75^{\circ}$, respectively, did not differ from $\mathrm{Ct}$ 2-13-4 or from Ct 1-1-1 (69 $)$ and $\mathrm{Ct} 4-21-3$ $\left(68^{\circ}\right)$. 'Tifway' and $\mathrm{Ct}$ 5-7-5 had lower shoot angles and were statistically isolated from other entries. Common bermudagrass had the lowest shoot angle $\left(43^{\circ}\right)$ and was significantly different from all other entries in the study.

Generalizations from analysis of shoot angles are that $\mathrm{Ct} 2-13-4, \mathrm{Ct} 1-14-5, \mathrm{Ct} 2-$ 19-1, and Ct 1-1-1 in various rankings had higher shoot angles at each date (Table 4) than other entries. Ct 4-21-3 ranked fifth at each date; however, its relationship to other genotypes varied greatly among dates. 'Tifway', like common bermudagrass, had significantly lower shoot angles than most African genotypes but was not statistically as low as common. One African genotype, Ct 5-7-5, was not significantly different from 'Tifway' on all three dates or from common on two of three dates.

This method appears to have more merit for use in screening bermudagrass germplasm for the identification of upright- or prostrate-growing plants. This was the only evaluation that identified differences in growth habits as a result of changing environmental conditions (i.e., $\mathrm{G} \times \mathrm{D}$ interaction). These changes include but are not limited to day length, angle of the sun, and cloudy weather. Evaluations of shoot type and leaf angle were not able to detect changes in plant growth in response to changing environmental conditions. By using shoot angles, one could select germplasm that maintains consistent plant architecture and eliminate those genotypes that are more sensitive to environmental conditions.

\section{Conclusions}

African bermudagrass is generally characterized as having an upright growth habit. The results presented indicate that variation in growth habits can be identified in germplasm of African bermudagrass. Although the majority of African genotypes did not branch extensively or have lower leaf and shoot angles, African genotype Ct 5-7-5 only differed statistically from a prostrate common bermudagrass on one of three dates of analysis for shoot angles and did not differ for shoot type or leaf angles. Although these two plants differ greatly with respect to stem diameter, leaf width, and leaf length, they share a low-growing, branching growth habit resulting in similar measurements for this study.

One might easily assume that 'Tifway' would fall between the measurements for African and common bermudagrass because it is an interspecific hybrid between these two species. To assume this is problematic. Bermudagrass is self-incompatible and heterogenous; therefore, the progeny produced from mating the two species could have a phenotypic appearance that ranges from resembling African bermudagrass to common bermudagrass. In this study, 'Tifway' appeared to have true intermediate status with respect to shoot type, but statistically was closer to the upright plants for leaf angles and to the prostrate plants for shoot angles. Although 'Tifway' was equal to some African genotypes, it was never in the highest or lowest statistical grouping and was always significantly different from the prostrate common bermudagrass genotype used in this study. However, as previously stated, the variation that exists for common bermudagrass in growth morphology is well documented (Harlan and de Wet, 1969; Harlan et al., 1970b). Therefore, it is reasonable to expect that if additional common genotypes were compared for these types of variables, several might be identified that would not differ from 'Tifway'.

In conclusion, attempts to categorize groups of African bermudagrass genotypes as having prostrate, intermediate, and upright growth habits were not successful. In addition, observations of shoot types and leaf angle measurements did not prove useful for the identification of upright- and prostrate-growing bermudagrass. Shoot angle measurements do appear to have potential for quantifying prostrate/upright growth habit differences between genotypes of African bermudagrass, common bermudagrass, and 'Tifway' hybrid bermudagrass. In addition, shoot angle measurements allowed for the identification and elimination of those genotypes that were more easily influenced by changing environmental conditions. It should be noted that the identification of genotypes using these techniques or selection by visual observation do not provide any value relative to their combining ability for breeding more prostrate or upright bermudagrass.

\section{Literature Cited}

Burt, M.G. and D.E. Christians. 1990. Morphological and growth characteristics of low- and high-maintenance Kentucky bluegrass cultivars. Crop Sci. 30:1239-1243.

de Wet, J.M.J. and J.R. Harlan. 1971. South African species of Cynodon (Gramineae). J. So. Afr. Bot. 37:53-56.

Eggens, J.L. 1981. Influence of mowing and tiller orientation on leaf measurements of Kentucky bluegrass. Can. J. Plant Sci. 61:1025-1026.

Gerken, D.A. 1994. Evaluation of African bermudagrass (Cynodon transvaalensis) as a putting surface. Oklahoma State Univ., Stillwater, MS Thesis.

Hanna, W.W. 1986. A bermudagrass primer and the Tifton bermudagrass. U.S. Golf Assoc. Green Section Record. Jan./Feb.:11-13.

Harlan, J.R. and J.M.J. de Wet. 1969. Sources of variation in Cynodon dactylon (L). Pers. Crop Sci. 9:774-778

Harlan, J.R., J.M.J. de Wet, W.W. Huffine, and J.R. Deakin. 1970a. A guide to the species of 
Cynodon (Gramineae). Bulletin B-673. Oklahoma State University Experiment Station.

Harlan, J.R., J.M.J. de Wet, and K.M. Rawal. 1970b. Geographic distribution of the species of Cynodon L. C. Rich (Gramineae). East African Agricultural and Forestry Journal. 36:220-226.

Harlan, J.R., J.M.J. de Wet, W.R. Richardson, W.W. Huffine, J. Deakin, S.P. Sen Gupta, and
A. Carpena. 1966. Biosystematics of the genus Cynodon (Gramineae). Progress report. Oklahoma State University Experiment Station.

Juska, F.V. and A.A. Hanson. 1964. Evaluation of bermudagrass varieties for general-purpose turf. Dept. Agr., Agr. Res. Ser., Agr. Hdbk. no. 270. U.S. Gov. Print. Office, Washington, DC.
Kenworthy, K.E., C.M. Taliaferro, G.F. Carver, D.L. Martin, J.A. Anderson, and G.E. Bell. 2006. Genetic Variation in Cynodon transvaalensis Burtt-Davy. Crop Sci. 46:2376-2381.

Nittler, L.W. and T.J. Kenny. 1976. Crown, tiller, and rhizome characteristics of Kentucky bluegrass cultivars. Agron. J. 68:395-397.

SAS Institute. 2000. SAS/STAT user's guide. SAS Inst. Inc., Cary, NC. 